\title{
Decision Support System for Alternative Site Selection of Kkn using Topsis
}

\author{
Agus Irawan \\ University of Serang Raya \\ Serang-Cilegon Street \\ KM 3 district taktakan, \\ Serang city, Banten province, \\ Indonesia
}

\author{
Rochmawati \\ Univeristy Of Serang Raya \\ Serang-Cilegon Street \\ KM 3 district taktakan, \\ Serang city, Banten province, \\ Indonesia
}

\begin{abstract}
Community Development Participation or KKN (Kuliah Kerja Nyata) is an annual activity at a university. The ultimate goal is the students learn to live in the community to identify the various developmental problems. The expectected outcomes are, the students were able to contribute ideas to solve the problems in a short term time by using the provision of knowledge gained during college. Therefore, the students together with the community discuss to find alternative solutions of the problem. These expectations often do not run as well. There are many factors behind the lack of conformity. One of them is caused by the lack of proper site selection for replacing the participants of Comunity Development Participation program to the community. During this relocatioin of Community Development Participation location by using the intuition supported by choosing the data of the area that is often not valid. A needed system that is capable to provide data information of Community Development Participation area and able to give priority on locating Community Development Participation. The system aims to be able to provide decision support models based on the availability of data and recent location selection is done by a combination of intuition and decision support modeling. TOPSIS method used in this study is to develop a Decision Support System (DSS) site of Community Development Participation selection that can be integrated into the information system. The results of the study are expected to be used as a decision making tool for the parties concerned, especially for Community Development Participation location.
\end{abstract}

\section{Keywords}

Community Development Participation, TOPSIS Method

\section{INTRODUCTION}

Community Development Participation for the Non Regular Students at the University of Serang Raya (UNSERA) is an annual event that is always held in order to equip students with the technical skills and practical as a provision to be a part of the community in the future. UNSERA typically is conducted in several places in Banten province based on some considerations. Some of these considerations include, distance to the campus location, site conditions, Community Development Participation locations including community conditions and the nature of the character of its citizens, licensing and availability of a complete profile KKN location. It is hoped that that Community Development Participation activities can be run optimally and the students are able to perform the activities of the community to share knowledge to students and vice versa.
However, implementation still often faces various problems, one of them is less precisely to choose the Community Development Participation location. It can be seen from the example, the emergence of public apathy towards Community Development Participation. Thus, some programs could not be fully implemented. The lack of the students' ability to adapt into the society, the miscommunication between the community and the students, the presence of excessive public demand to students. False paradigm of society to students that assumes the students bring mission and programs of the government equipped with a lot of funds, as well as many more problems occured in the field.

LPPM UNSERA as one of the institutions responsible for managing and controlling operational Community Development Participation activities, continue to do the evaluation and improvement of the system of replacement and implementation of student Community Development Participation site. This is intended to ensure the students in order to provide a place in the form of employment activity in the community by students, can be carried out in accordance with the purpose, role and functions, both for students and for the people who were at Community Development Participation site. One form of improvements made to the activities in 2015 are, LPPM UNSERA organizing Community Development Participation in a longer duration. In general, learning activities conducted by two main activities, firstly, observing and recognizing Community Development Participation location to gather as much information as well as a form of early introduction to the public. Second, the implementation of Community Development Participation is as a continuation of the first activity. Consideration done as an intention that Community Development Participation activities can be conducted properly in accordance with the programs that have been compiled and adapted for conducting early stage. In addition to the above considerations, of course analysis tools are needed to assist the implementation of Community Development Participation, especially in the process of selection site of Community Development Participation.

To support a new breakthrough in the implementation of Community Development Participation, analysis tool in the form of a decision support to determine the exact location of Community Development Participation by considering several required factors, both internal and external. The results of the analysis tools are expected to reduce problems of Community Development Participation that is often occured every year. In addition, the final result is expected to give consideration later location of Community Development Participation able to adjust various conditions both in terms of society, the ability of organizers of Community Development Participation and 
also lecturers. Analysis tools in question do not only contains of the model DSS, but it also includes a map-related to the System of Information of the previous Community Development Participation so it can be used as a material for analysing and supporting data SPK itself. Decision-making techniques to the concept of multi-attribute decision making (MADM) will be used in this study. This concept uses many criteria for the selection of a number of alternatives that will be selected. Several methods are commonly used MADM Simple aditive Weighting (SAW), Weighting Product (WP), TOPSIS, ELECTRE and AHP. In the research, site selection analysis methods of Community Development Participation will be done with TOPSIS approach.

TOPSIS can be done with the consideration that the alternative selected by selecting the the closest area from the positive ideal solution value and condition of the farthest distance from the negative ideal solution (Yonn and Hwang (1981) in Imbar and Hartanto (2011)). The comparison between these two values will determine the final value for each alternative. In addition, the concept of solving problems of TOPSIS has a simple and easy to understand, efficient, and able to measure the relative performance of each of the alternatives (Kusumadewi et al, 2006).

Research results are expected to provide input in the form of a decision support analysis in the form of several alternative areas that will serve the location of Community Development Participation. In addition, the results of the analysis can be combined with a new policy to be implemented in 2015 and beyond, so that the problems related to the choice of location is less precise and the problems can be solved as early as possible.

\section{THEORETICAL BACKGOUND}

\subsection{KKN}

Student Study Service (KKN) is one form of education provided to the students through the learning experience in the community so as to directly identify the various issues related to the process of development that the society itself (Zulchaidir, 2014).

KKN undergone many developments since the inception by the University of Gajah Mada in 1951. Suherman (2011) suggested that the development of the KKN is divided into six important stages. First, the pilot period is done in the period 1971 - 1976. This period started with the idea associated with the need $\mathrm{KKN}$ for students as a form of community service. The second, referred to as the transitional period immersion period 1977 - 1979 in which the implementation of $\mathrm{KKN}$ is divided into two main activities, namely as intra limited activities and as a compulsory subject.

The third stage is a period of consolidation that took place in the period 1979 - 1990. In this phase KKN becomes a mandatory activity for students and began to plunge directly into the community. Completion of responsibility DPL, assessment results and improvement KKN. implementation requirements for students who may not be in a state of pregnancy, corrected at this stage. The fourth stage takes place in the period 1990 - 1997 which began to experience growth and laying the basis for the implementation of KKN both National and regional levels.

The fifth stage took place in the period 1998 - 2005 which is known as the period of transformation. In this period there is a change pattern of implementation by the enactment KKN KKN Alternative (1999), KKN Sibermas (200) and Thematic KKN (2002). In the sixth resistant occur in the period 2004 -
2006 is referred to as contextual Thematic KKN period where KKN involving communities in the planning and determination of the activities to be implemented on the so expected to have power for the community. The last stage of the KKN PPM period from 2006 until now. In this seventh stage of Student study services is Learn for Community Empowerment (PPM) where not only students who make the learning process but the community also. KKN PPM is expected to increase empathy, caring, cooperation of a multidisciplinary science students are then encouraged the creation of a learning community.

\subsection{Decision Support System}

Decision support system (DSS) is an information system that is interactive and able to provide information, modeling and manipulation of data at a time so that it can be used by policy makers related to make decision (Ridaini, 2014). The purpose of the development of DSS is to help resolve the problems that are semi-structured, helping managers make decisions and improve the effectiveness of decision-making. However DSS in this case does not mean to the efficiency of the decision itself (Wikipedia, 2013).

Andayati (2010) in his study suggests that CMS has three characteristics. First, interactive capabilities, which the DSS is able to provide decision makers with rapid access to the data and information required. Both Flexibility, where the DSS should be able to support managers in various fields in accordance with its function. Third, DSS should be able to integrate a model which allows the decision maker to manipulate the model as needed. Figure 1 below is the configuration of the SPK.

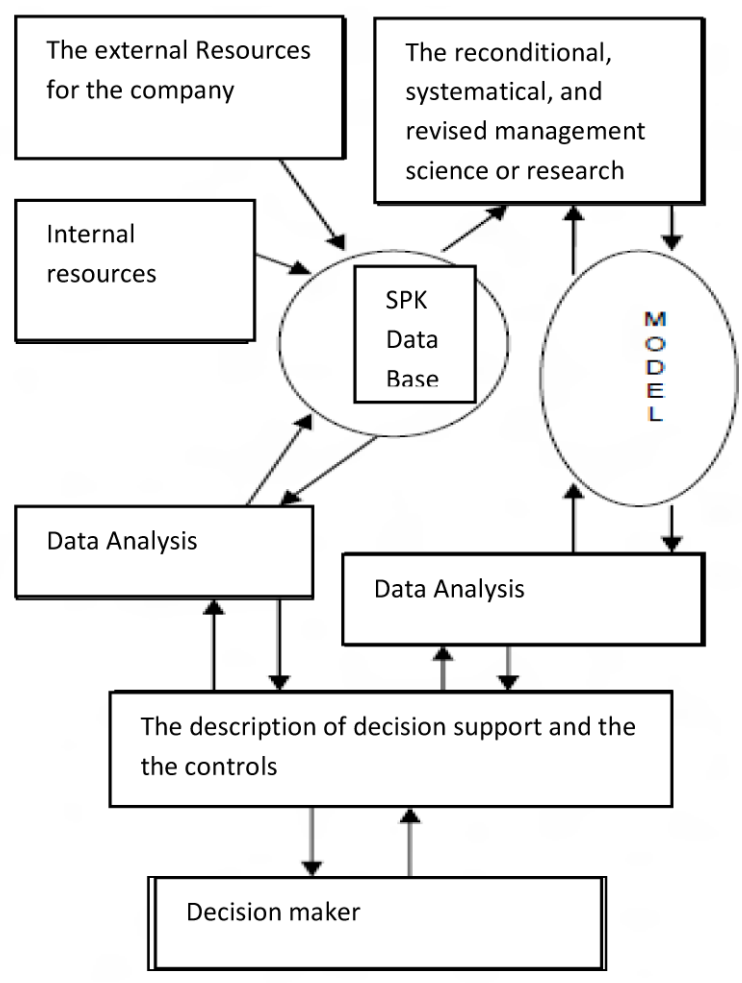

Figure 1.DSS Configuration

\subsection{TOPSIS}

TOPSIS is one method of decision-making to the concept of multi-attribute decision making (MADM) that in the selective alternative by the selecting the condition that is the closest distance from the positive ideal solution value and condition 
of the farthest distance from the negative ideal solution. Ranking of the alternatives carried out in preference matrix which contains the values of an alternative to certain criteria. Then normalized preference matrix is then multiplied by the weight of predetermined preferences.

The normalized weighted matrix results are then calculated the positive and negative ideal solution. After the calculation of distance alternative to the positive and negative ideal solutions do. The last step is calculating the preference value of each alternative based on the distance that has been calculated before.Alternatives range is done after getting preference value. Here are the steps TOPSIS method in complete :

1. Defining the problems to be solved by the method of TOPSIS

2. Make a decision matrix according to the problems to be solved with the following conditions:

$$
D=\left[\begin{array}{ccc}
x 11 & x 12 \ldots & x 1 n \\
x 21 & x 22 \ldots & x 2 n \\
\ldots & \ldots & \ldots \\
x m 1 & x m 2 \ldots & x m n
\end{array}\right]
$$

3. Then do the normalization matrix equation

$$
r_{i j}=\frac{x_{i j}}{\sqrt{\sum_{i=1}^{m} x_{i j}^{2}}}
$$

Where is the payoff matrix rij normalization of the basic matrix of the problem, with $i=1,2,3, \ldots . \mathrm{m}$, and $\mathrm{j}=$ $1,2,3 \ldots \mathrm{n}$. While xij is a basic matrix to be normalized. For every i showed rows of the matrix, and for each $\mathrm{j}$ show the columns of each matrix.

4. Make a matrix rij normalization using weights rating thus obtained matrix normalized weight rating, the equation used is as follows

$$
\mathbf{y}_{\mathrm{ij}}=\mathbf{w}_{\mathrm{i}} \cdot \mathbf{r}_{\mathrm{ij}}
$$

5. where yij is a weighted matrix rating, wi is the weight rating to $i$, and rij is the payoff matrix normalization in step two. For $\mathrm{i}=1,2, \ldots, \mathrm{m}$, and $\mathrm{j}=$ $1,2, \ldots, n$. In this case, the weight rating should be determined based on the number of decision variables are being finalized.

6. Determine the positive ideal solution $(\mathrm{A}+)$ and negative ideal solution (A-) rating weighted by the value matrix in step 3 . The following equation is used to find the value of a positive ideal solution and negative ideal solution value

$$
\begin{aligned}
& A^{+}=\left(y_{1}^{+}, y_{2}^{+}, \ldots, y_{n}^{+}\right) \\
& A^{-}=\left(y_{1}^{-}, y_{2}^{-}, \ldots, y_{n}^{-}\right)
\end{aligned}
$$

Under the condition :

$\mathrm{y}^{+}=\max \mathrm{y}_{\mathrm{ij}}$ if $\mathrm{j}$ is an attribute benefits and;

$\mathrm{y}^{+}=\min \mathrm{y}_{\mathrm{ij}}$ if $\mathrm{j}$ is an attribute costs

$\mathrm{y}_{\mathrm{i}}^{-}=\max \mathrm{y}_{\mathrm{ij}}$ if $\mathrm{j}$ is an attributecostsand;

$\mathrm{y}_{\mathrm{i}}^{-}=\min \mathrm{y}_{\mathrm{ij}}$ if $\mathrm{j}$ is an atribut benefits

7. Determine the distance between the weighted value of each alternative to the positive ideal solution $\left(D_{i}^{+}\right)$and negative ideal solution $\left(D_{i}^{-}\right)$.
To determine the distance between the weighted value of each alternative to the positive ideal solution $\left(D_{i}^{+}\right)$, use the following equation

$$
x D_{i}^{+}=\sqrt{\sum_{i=1}^{n}\left(y_{i}^{+}-y_{i j}\right)^{2}}
$$

Moderate to calculate the distance between the weighted value of each alternative against the negative ideal solution $\left(D_{i}^{-}\right)$, use the following equation :

$$
D_{i}^{-}=\sqrt{\sum_{i=1}^{n}\left(y_{i j}-y_{i}^{-}\right)^{2}}
$$

8. The final step is to calculate the value of a preference for any alternative to the equation :

$$
V_{i}=\frac{D_{i}^{-}}{D_{i}^{-}+D_{i}^{+}}
$$

\section{ANALYSIS}

\subsection{Problem Analysis}

The problem that is being faced is how to determine the ideal location of Community Development Participation from the standpoint of TOPSIS, as for the data to be processed is the data of villages / wards based on the criteria that has been determined as follows: the distance, Number of Preprosperous family in percent and Population Density. Then each of the criteria in comparison to then be weighted interest rate among the criteria

\subsection{Needs Of Data Analysis}

Analysis of the need data are pieces of data that they got to be processed and produced the desired output. Data were processed in the form of villages and villages in the district of Serang totaling 326 Villages and Towns of Serang consists of 66 villages. Here is the input data to be processed:

\section{Table 3.1 Needs of Data}

\begin{tabular}{|c|c|c|}
\hline NO & $\begin{array}{c}\text { Needs of } \\
\text { data }\end{array}$ & Description \\
\hline 1 & $\begin{array}{c}\text { Villages } \\
\text { Data }\end{array}$ & $\begin{array}{c}\text { The data consists of the name of the } \\
\text { village, distanceto the village, population } \\
\text { density, the percentage of keluarga pra } \\
\text { sejahtera }\end{array}$ \\
\hline 2 & $\begin{array}{c}\text { Sub } \\
\text { Districts }\end{array}$ & Consists of the name of the sub-district \\
\hline
\end{tabular}

The weight of the value of Criteria and Alternatives:

Table 3.2The degree of importance (weight)

\begin{tabular}{|c|c|}
\hline Value & $\begin{array}{c}\text { Degree of } \\
\text { importance }\end{array}$ \\
\hline 1 & Not good \\
\hline 2 & Deficient \\
\hline 3 & Sufficient \\
\hline 4 & Good \\
\hline 5 & Very good \\
\hline
\end{tabular}




\subsection{Application of Topsis Method}

Following the rule of the degree of importance (weight) is determined, then make the decisive criteria and the degree of interest from each of the criteria, which is depicted in the following table:

Table 3.3 Data criteria and the degree of importance (weights)

\begin{tabular}{|c|c|c|c|}
\hline $\begin{array}{c}\text { Criteria } \\
(\mathbf{C})\end{array}$ & $\begin{array}{c}\text { Distances } \\
\text { from campus } \\
(\text { cost }) \\
(\mathrm{C} 1)\end{array}$ & $\begin{array}{c}\text { pre-prosperous } \\
\text { family (Benefit) } \\
(\mathrm{C} 2)\end{array}$ & $\begin{array}{c}\text { Population } \\
\text { density } \\
\text { (benefit) } \\
(\mathrm{C} 3)\end{array}$ \\
\hline Weight & 4 & 5 & 3 \\
\hline
\end{tabular}

Next step is to make a decision matrix. Decision matrix made based on the data the village that consists of data in the kilometer distance from the campus, the number of preprosperous family in percentage and population density in inhabitants / km2. To implementation TOPSIS method only sample data will be use, Tembilak, Kadukempong and Padarincang, the data represent by table as follows :

Table 3.4 Sample data Of alternative

\begin{tabular}{|c|c|c|c|}
\hline Alternative & $\begin{array}{c}\text { Distances } \\
\text { from } \\
\text { campus } \\
\text { (cost) } \\
(\mathrm{C} 1)\end{array}$ & $\begin{array}{c}\text { pre- } \\
\text { prosperous } \\
\text { family } \\
\text { (Benefit) } \\
\text { (C2) }\end{array}$ & $\begin{array}{c}\text { Population } \\
\text { density } \\
\text { (benefit) } \\
\text { (C3) }\end{array}$ \\
\hline Tembiluk(a1) & 31 & 28.746 & 1.726 \\
\hline Kadukempong(a2) & 40.6 & 13.590 & 1.155 \\
\hline Padarincang(a3) & 35.5 & 9.046 & 3.856 \\
\hline
\end{tabular}

Alternative data of the distance from the campus, preprosperous family and the population density will be used as a decision matrix that will be directly processed to create a matrix normalized.

Based the decision matrix in table 3.4 above, then the next step is to create a normalized matrix by the equations:

$$
r_{i j}=\frac{x_{i j}}{\sqrt{\sum_{i=1}^{m} x_{i j}^{2}}}
$$

So based on the equation of the weights on alternatives to the criterion of the village within the campus, then the calculation is as follows:

$$
\begin{gathered}
x_{a 1 c 1}=\frac{31}{\sqrt{31^{2}+40,6^{2}+35,5^{2}+\text { etc } \ldots}}=\frac{31}{561,489} \\
=0.05505 \\
x_{a 2 c 1}=\frac{40,6}{\sqrt{31^{2}+40,6^{2}+35,5^{2}+\text { etc } \ldots}}=\frac{40,6}{561,489} \\
=0.07186 \\
x_{a 3 c 1}=\frac{35,5}{\sqrt{31+40,6^{2}+35,5^{2}}+\text { etc. }}=\frac{35,5}{6561,489} \\
=0.06284
\end{gathered}
$$

Calculation of normalization for the criteria of percentage of pre-prospereus families :

$$
\begin{gathered}
x_{a 1 c 1}=\frac{28,746}{\sqrt{28,746^{2}+13,59^{2}+9,046^{2}+\text { etc } \ldots}}=\frac{28,746}{444,494} \\
=0.064381
\end{gathered}
$$

Normalization calculation for population density criteria:

$$
\begin{gathered}
x_{a 1 c 3}=\frac{1726,276}{\sqrt{1726,276^{2}+1155,783^{2}+3856,714^{2}+\text { etc. }}} \\
=\frac{1726,276}{55231,684}=0.03125 \\
x_{a 2 c 3}=\frac{1155,783}{\sqrt{1726,276^{2}+1155,783^{2}+3856,714^{2}+\text { etc } \ldots}} \\
=\frac{1155,783}{55231,684}=0.02090 \\
x_{a 3 c 3}=\frac{3856,714}{\sqrt{1726,276^{2}+1155,783^{2}+3856,714^{2}+\text { etc } \ldots}} \\
=\frac{3856,714}{55231,684}=0,06492
\end{gathered}
$$

Resulting in a matrix normalized as follows:

Table 3.5 matrix normalized

\begin{tabular}{|c|c|c|c|}
\hline Alternatives & C1 & C2 & C3 \\
\hline Tembiluk (a1) & 0.05505 & 0.06438 & 0.03125 \\
\hline Kadukempong (a2) & 0.07186 & 0,03043 & 0.02090 \\
\hline Padarincang (a3) & 0.06284 & 0.02026 & 0.06492 \\
\hline
\end{tabular}

Once the normalized matrix is made then the next step to make normalization weighted matrix, at this stage the normalized matrix is multiplied by the weight matrix criteria, the following are examples of multiplicative form

$\begin{aligned} & {\left[\begin{array}{lll}0.05505 & 0.06438 & 0.03125 \\ 0.07186 & 0.03043 & 0.02090 \\ 0.06284 & 0.02026 & 0.06492\end{array}\right] \times\left[\begin{array}{lll}5 & 4 & 3\end{array}\right]=} \\ & {\left[\begin{array}{lll}0.22019 & 0.32191 & 0.09357 \\ 0.28746 & 0.15219 & 0.06270 \\ 0.25135 & 0.10130 & 0.19476\end{array}\right] }\end{aligned}$

The results of the normalization of the weighted value is as follows:

Tabel 3.6 Normalized weighted matrix

\begin{tabular}{|c|c|c|c|}
\hline & $\mathrm{C} 1$ & $\mathrm{C} 2$ & $\mathrm{C} 3$ \\
\hline A1 & 0,22019 & 0,32191 & 0,09357 \\
\hline A2 & 0,28746 & 0,15219 & 0,06270 \\
\hline A3 & 0,25135 & 0,10130 & 0,19476 \\
\hline
\end{tabular}

To find a positive ideal solution $(\mathrm{y}+)$ each alternative based on criteria highest value as follows : 
$\mathrm{y}^{+}{ }_{1}=\min (0,22019,0,28746,0,25135$, etc.. $)=0,01062$

$\mathrm{y}^{+}{ }_{2}=\max (0,32191,0,15219,0,10130$, etc.. $)=0,60358$

$\mathrm{y}_{3}^{+}=\max (0,09357,0,06270,0,19476$, etc.. $)=1,10815$

To find the ideal solution Negative $\left(\mathrm{A}^{-}\right)$each alternative based on the value of the criteria which has the lowest value in the alternative:

$\mathrm{y}^{-}=\max (0,22019,0,28746,0,25135$, etc.. $)=0,45424$

$\mathrm{y}_{2}{ }_{2}=\min (0,32191,0,15219,0,10130$, etc.. $)=0,00823$

$\mathrm{y}_{3}{ }_{3}==\min (0,09357,0,06270,0,19476$, etc.. $)=0,00452$

So the value $\mathrm{A}^{+}$and nilai $\mathrm{A}^{-}$obtained are as follows :

Tabel 3.7 value $\mathrm{A}^{+}$and $\mathrm{A}^{-}$

\begin{tabular}{|c|c|c|c|}
\hline & $\mathbf{C 1}$ & $\mathbf{C 2}$ & $\mathbf{C 3}$ \\
\hline $\mathbf{A}^{+}$ & 0,01062 & 0,60358 & 1,10815 \\
\hline $\mathbf{A}^{-}$ & 0,45424 & 0,00823 & 0,00452 \\
\hline
\end{tabular}

Looking distances normalized weighted value with positive ideal solution $\left(\mathrm{D}^{+}\right)$and negative ideal solution $\left(\mathrm{D}^{-)}\right.$

To find a distance value normalization weighted value of each alternative with positive ideal solution using the equation

$$
D_{i}^{+}=\sqrt{\sum_{i=1}^{n}\left(y_{i}^{+}-y_{i j}\right)^{2}}
$$

The calculations performed for each alternative are as follows:

$D_{a 1}^{+}$

$=\sqrt{(0,22019-0,01062)^{2}+(0,32191-0,60358)^{2}+(0,09375-1,10815)^{2}}$

1,07341

$D_{a 2}^{+}=$

$\sqrt{(0,28746-0,01062)^{2}+(0,15219-0,60358)^{2}+(0,06270-1,10815)^{2}}=$ 1,17187

$D_{a 3}^{+}$

$=\sqrt{(0,25135-0,01062)^{2}+(0,10130-0,60358)^{2}+(0,19476-1,10815)^{2}}$

$=1,06981$

For calculating the negative ideal solution using the following equation:

$$
D_{i}^{-}=\sqrt{\sum_{i=1}^{n}\left(y_{i j}-y_{i}^{-}\right)^{2}}
$$

So the calculation of the distance of each alternative to the negative ideal solution is as follows:

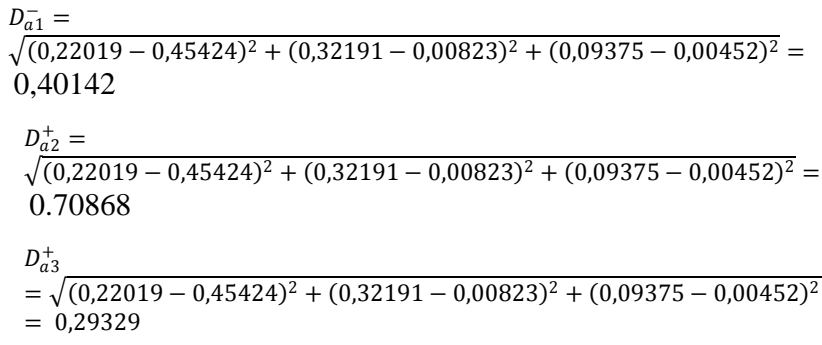

So that the value $\mathrm{D}^{+}$and $\mathrm{D}^{-}$each alternative is shown in the following table:
Tabel 3.8 Value $\mathrm{D}^{+}$and $\mathrm{D}^{-}$

\begin{tabular}{|l|l|l|}
\hline & $\mathrm{D}^{+}$ & \multicolumn{1}{|c|}{$\mathrm{D}^{-}$} \\
\hline A1 & 1,07341 & 0,40142 \\
\hline A2 & 1,17187 & 0,22787 \\
\hline A3 & 1,06981 & 0,29329 \\
\hline
\end{tabular}

Preference value is calculated using the following equation :

$$
V_{i}=\frac{D_{i}^{-}}{D_{i}^{-}+D_{i}^{+}}
$$

From the equation then calculated for each alternative value of preference:

$$
\begin{aligned}
& \mathrm{V}_{\mathrm{a} 1}=\frac{0,40142}{0,40142+1,07341}=0,272181 \\
& \mathrm{~V}_{\mathrm{a} 2}=\frac{0,22787}{0,22787+1,17187}=0,162795 \\
& \mathrm{~V}_{\mathrm{a} 1}=\frac{0,29329}{0,29329+1,06981}=0.215164
\end{aligned}
$$

From the calculation of such preference, the value generated by each alternative and then in the ranking is based on the greatest value. Then presented the results of his preference as follows :

Tabel 3.9 Preference value of each alternative

\begin{tabular}{|l|c|}
\hline \multicolumn{1}{|c|}{ Alternatif } & Preference Values \\
\hline Tembilak (A1) & 0,272181 \\
\hline Padarincang (A2) & 0.162795 \\
\hline Kadukempong (A3) & 0.215164 \\
\hline
\end{tabular}

So based on the results of the preference value in the ranking of corruption ideal place based on analysis using TOPSIS method to get results Cipare village in the district of SerangSerang occupies the first recommendation to 0.71992 while the preference value for the village Tembilak, Padarincang and Kadukempong sequentially position 123, 329 and 389 .

\section{CONCLUSION}

The conclusion of this study, among others, Stages analysis with TOPSIS method provides results in the form of rankings based on the preferences of the greatest value. The rankings illustrate the priority level of $\mathrm{KKN}$ in recommending where appropriate based on the criteria of distance from campus, the total percentage of underprivileged families and population density. TOPSIS approach will provide convenience in data processing village in the district Serang and Serang city, so as to generate a recommendation $\mathrm{KKN}$ in accordance with the priority level based on criteria.

\section{REFERENCES}

[1] Imbar, RV., dan Hartanto, BS, 2011, Aplikasi Sistem Informasi Sumber Daya Manusia dengan Fitur DSS Menggunakan Metode Topsis pada PT. X, Jurnal Informatika, Vol. 7, No. 2, December 2011: 125 - 144

[2] Kusumadewi, Sri, dkk. 2006. Fuzzy Multi Attribute Decision Making. Yogyakarta: Graha Ilmu 
[3] Suherman, W.S, 2011, Pemberdayaan Masyarakat Melalui Kuliah Kerja Nyata, Kumpulan Makalah Pembekalan KKN UNY 2011, hal 21 - 29

[4] Andayati, D, 2010, Sistem Pendukung Keputusan PraSeleksi Penerimaan Siswa Baru (PSB) Online Yogyakarta, Jurnal Teknologi, Vol. 3, No. 2, Desember 2010, hal. 145 - 153

[5] Zulchaidir, 2014, Studi Tentang Pelaksanaan Kuliah Kerja Nyata Angkatan XXXIX Tahun 2013 Oleh Lembaga Pengabdian Pada Masyarakat Universitas Mulawarman Samarinda, eJournal llmu Administrasi Negara, 2014, 3 (2): 938-951

[6] Ridaini, 2014, Sistem Pendukung Keputusan Pemilihan Objek Wisaya Di Aceh Tengah Menggunakan Metode TOPSIS, Makalah Ilmiah Informasi dan Teknologi Ilmiah (INTI), Vol. IV, Nom. 3, Oktober 2014

[7] Kurniasih, D,L, 2013, Sistem Pendukung Keputusan Pemilihan Laptop Dengan Metode TOPSIS, Jurnal Pelita Informatika Budi Darma, Vol, III, No. 2, April 2013

[8] Perdana, N, G, P dan Widodo, T, Sistem Pendukung Keputusan Pemberian Beasiswa Kepada Peserta Didik Baru Menggunakan Metode TOPSIS, Prosiding Seminar Nasional Teknologi Informasi dan Komunikasi Terapan 2013 (SEMANTIK 2013), Semarang, 16 November 2013.

[9] Mardiyati, U., Utomo, F,S dan Yuniarsih, R, 2011 , Technique for Order Preference by Similarity to Ideal
Solution sebagai Metode Multi Attribute Decision Making untuk Menentukan Rekomendasi Penerima Beasiswa BBM dan PPA di STMIK AMIKOM Purwokerto, Prosiding Seminar Nasional Pengaplikasian Telematika SINAPTIKA 2011

[10] Imbar, R,V dan Hartanto, B, S, 2011, Aplikasi Sistem Informasi Sumber Daya Manusia dengan Fitur DSS Menggunakan Metode Topsis pada PT. X, Jurnal Informatika, Vol. 7, No. 2, December 2011: 125 - 144

[11] Wikipedia, 2013, Sistem pendukung keputusan, Akses tanggal 15 Maret 2015. Availableat : http://id.wikipedia.org/wiki/Sistem_pendukung_keputusa

[12] Jamila dan Hartati, S, 2011, Sistem Pendukung Keputusan Pemilihan Subkontrak Menggunakan Metode Entropy dan TOPSIS, Jurnal IJCCS, Vol.5, No. 2, Juli 2011

[13] Wahyuningsih, Ni Made Ayu Ary, Darmawiguna, I Gede Mahendra dan Kesiman, Made Windu Antara, 2013, Pengembangan Sistem Pendukung Keputusan Berbasis Metode TOPSIS (Technique for Order Preference by Similarity to Ideal Solution) untuk Penempatan Mahasiswa Kuliah Kerja Nyata : Studi Kasus di Lembaga Pengabdian pada Masyarakat Universitas Pendidikan Ganesha, Kumpulan Artikel Mahasiswa Pendidikan Teknik Informatika (KARMAPATI), Volume 2, Nomor 6, August 2013 